\title{
TRANSACTIONS OF THE ROYAL HISTORICAL SOCIETY
}

FIFTH SERIES

Volume 30

\section{LONDON}

OFFICES OF THE ROYAL HISTORIGAL SOGIETY UNIVERSITY GOLLEGE LONDON, GOWER ST, WCIE 6BT I 980 
(C) Royal Historical Society

ISBN o 901050687

Made and printed in Great Britain by Butler \& Tanner Ltd., Frome and London 


\section{CONTENTS}

Books of Orders: the Making of English Social Policy, I577-1631. By Paul Slack, M.A., D.Phil., F.R.Hist.S.

The Political Beliefs of Winston Churchill. By Paul Addison, M.A., D.Phil., F.R.Hist.S.

Family, Community and Cult on the Eve of the Gregorian Reform. By R. I. Moore, M.A., F.R.Hist.S.

Food Production and Policy in the United Kingdom, 1914-1918 (The Alexander Prize Essay). By P. E. Dewey, B.A., Ph.D., F.R.Hist.S.

From Office-Holding to Civil Service: the Genesis of Modern Bureaucracy (The Prothero Lecture). By G. E. Aylmer, M.A., D.Phil., F.B.A., F.R.Hist.S.

Public and Private Bureaucracies in England and Wales in the Fifteenth Century. By R. A. Griffiths, B.A., Ph.D., F.R.Hist.S.

Bureaucracy and Ideology: Britain and India in the Nineteenth Century. By Professor E. T. Sтокеs, M.A., Ph.D.

'Toward the Iron Cage of Future Serfdom'? On the Methodological Status of Max Weber's Ideal-Typical Concept of Bureaucratization. By Professor Wolfgang J. Mommsen, Dr.Phil., F.R.Hist.S.

British Civil Service and the War Economy. Bureaucratic Conceptions of the 'Lessons of History' in 1918 and 1945 . By J. M. LEE, M.A., B.Litt., F.R.Hist.S. Presidential Address: The Rise and Fall of English Landed Families, I600-I800: II. By Sir JohN HabakкuK, M.A., F.B.A. 
Report of Council, 1978-79

Alexander Prize

David Berry Prize

$23 \mathrm{I}$

Whitfield Prize

234

Officers and Council r 979

235

List of Fellows

237

List of Associates

List of Corresponding Fellows

288

List of Publications

290 